\title{
Palaeoecological evidence for Mesolithic to Medieval climatic change and anthropogenic impact on the Alpine flora and vegetation of the Silvretta Massif (Switzerland/Austria)
}

\author{
Benjamin Dietre ${ }^{\mathrm{a}, *}$, Christoph Walser ${ }^{\mathrm{b}}$, Karsten Lambers ${ }^{\mathrm{b}}$, Thomas Reitmaier ${ }^{\mathrm{c}}$, \\ Irka Hajdas ${ }^{\mathrm{d}}$, Jean Nicolas Haas ${ }^{\mathrm{a}}$ \\ ${ }^{a}$ Institute of Botany, University of Innsbruck, Sternwartestrasse 15, A-6020 Innsbruck, Austria \\ ${ }^{\mathrm{b}}$ Institute of Archaeology, Heritage Sciences and Art History, University of Bamberg, D-96045 Bamberg, Germany \\ ${ }^{\mathrm{C}}$ Archaeological Service of the Canton of Grisons, Loëstrasse 26, CH-7001 Chur, Switzerland \\ ${ }^{\mathrm{d}}$ Laboratory of Ion Beam Physics, ETH Zürich, Schafmattstrasse 20, CH-8093 Zürich, Switzerland
}

Keywords:

Holocene

Eastern Alps

Palaeoclimate

Timberline

Pastoral Activity

Non-Pollen Palynomorphs

\begin{abstract}
A B S T R A C T
In a high altitude region such as the Silvretta Alps (Switzerland/Austria), past and extant settlement activities are known to have had large influences on the alpine flora and vegetation. The Silvretta Massif harbors more than 230 archaeological sites above $2000 \mathrm{~m}$ a.s.l. on a total area of $550 \mathrm{~km}^{2}$, from the Mesolithic period to Modern Times, but received little attention in these matters up to recently. The Fimba Valley within the Silvretta area with 47 known archaeological sites (6 prehistoric, 21 from the Medieval and/or Modern Times, 20 undated) located over an area of $62 \mathrm{~km}^{2}$ provides evidence of a broad range of former human presence, as well as peat records allowing the reconstruction of Holocene climatic change and anthropogenic impact on past vegetation. Here, we present a high resolution, multi proxy study (including pollen, cryptogam spores, and non pollen palynomorphs) on a $177 \mathrm{~cm}$ long radiocarbon dated peat core from the Las Gondas Bog in the Fimba Valley (2363 m a.s.l.). Palynological evidence adds and confirms previous dendrochronological results, revealing extensive high Pinus cembra (Arolla pine) stands around the bog at 10,400 cal BP and between ca. 86006700 cal. BP, more than 300 altitudinal meters above today's timberline, and belonging therefore to the highest population known for Central Europe. In addition, our palaeoecological results correlate well with the archaeologically known human impact during the Neolithic, Iron Age and Medieval periods. The exploitation of alpine landscape resources (cultivation of cereals in the valleys) and livestock grazing (in the subalpine and alpine areas) has therefore a long tradition going back at least for 6200 years in the Silvretta region.
\end{abstract}

\section{Introduction}

Understanding today's climate change and its impact on human societies is dependent on the accurate knowledge of historical and prehistorical interactions between humans and their environment. However, few environmental archaeological studies have explored palaeoecological proxies in the context of archaeological settle ments at subalpine and alpine altitudes so far (Ejarque et al., 2010). The impact of past climatic change remains less investigated in alpine than in pre alpine environments (Kofler et al., 2005). The Silvretta Massif with its passes is one of the possible (pre )historical

\footnotetext{
* Corresponding author.

E-mail addresses: benjamin.dietre@gmail.com, benjamin.dietre@uibk.ac.at (B. Dietre).
}

exchange routes through the Eastern Alps (Reitmaier, 2012; Reitmaier et al., 2013). Silex flints from the Lake Garda area (Northern Italy) were found in several archaeological sites north of the Alps, notably in the Neolithic pile dwelling village of Arbon Bleiche 3, Lake Constance, Switzerland (Jacomet, 2008), implying their long range transport. In addition, mountainous regions such as the Silvretta Alps are highly sensitive to microclimatic alter ations. Such perturbations, even if small, may have had a large ef fect on subalpine settlement activities and the former use of natural resources (for instance, timberline lowering due to high alpine climatic change and/or pastoral activities). Climatic fluctuations may also have influenced anthropogenic activities above the former timberline in several regions of the Alps as reflected in the numerous archaeological sites dating from the Mesolithic to Me dieval Times. Until 2007, the Silvretta archaeological potential 
received little attention, but since then more than 230 archaeo logical sites (e.g. settlement structures, abris, and livestock enclo sures) were discovered above $2000 \mathrm{~m}$ a.s.l., inventoried, and excavated on this $550 \mathrm{~km}^{2}$ area, from which 47 sites (including 6 prehistoric, 21 from the Medieval and/or Modern Times) are located in the Fimba Valley (Reitmaier, 2012; Reitmaier et al., 2013).

Alpine palynological studies are of prime importance to recon struct past vegetation as well as to reveal human presence and its impact due to the exploitation and management of natural land scape resources (Thiébault, 2010). It is well acknowledged that all types of vegetation assemblage are significantly impacted by hu man presence, livestock grazing and landscape management. There is global consensus that pollen and spores are of invaluable interest to reconstruct past vegetation composition and its evolution and to reveal the impact of climatic change and human presence on nat ural resources (Behre, 1981, 1988; Berglund et al., 1991; Latałowa, 1992; van Geel et al., 2003; Graf and Chmura, 2006; Brun, 2011). Furthermore, non pollen palynomorphs (NPPs, such as algal cysts, fungal spores, zoological microfossils) help to interpret general pollen data, especially because of the good knowledge of their ecological requirements and their local dispersion (van Geel et al., 2003; Graf and Chmura, 2006; van Geel and Aptroot, 2006). Moreover, local scale palaeoecological studies are most likely to reveal human-environment relationships, especially regarding coprophilous fungi, which can be considered as indicators for livestock grazing pressure (Blackford and Innes, 2006; Davis and Shafer, 2006; Dearing et al., 2006; Gauthier et al., 2010; Laine et al., 2010; Dietre et al., 2012). NPPs therefore help as proxies to interpret results obtained by environmental archaeology (van Geel et al., 2003).
Here, we present the palaeoecological study of the Las Gondas Bog, Fimba Valley, Switzerland, performed on a peat core from the central, deepest part of this bog, which was built up after the retreat of the Late Glacial ice masses around 11,000 cal Bp (Hertl and Kerschner, 2001). The bog area has formerly been studied on a nearby $148 \mathrm{~cm}$ long peat core in a first overview work (Pott et al., 1995; Bauerochse and Katenhusen, 1997) for pollen and cryptogam spores. In the present new study, a high resolution dated multi proxy palaeoecological approach was adopted, combining the analysis of plant pollen and cryptogam spores, as well as NPPs and macrofossils, on a $177 \mathrm{~cm}$ long peat core from the Las Gondas Bog, more than 300 altitudinal meters above today's timberline.

\section{Regional setting}

The Silvretta mountain range (Switzerland/Austria, Fig. 1) is a $771 \mathrm{~km}^{2}$ massif located in the center of the Alps, within the Central Eastern Alps (Brachmann, 1979). Geologically, the Silvretta Massif is mainly composed of gneiss, marble, and quartzite due to high metamorphism (Frei et al., 1995). The highest mountain peak is Piz Linard (3411 $\mathrm{m}$ a.s.l.) on the Swiss side of the massif. The mean annual precipitation is $900 \mathrm{~mm}$ on the northern side, and $695 \mathrm{~mm}$ on the southern side of the Silvretta Alpine ridge, and the annual mean temperatures are equal to $3{ }^{\circ} \mathrm{C}$ and $5{ }^{\circ} \mathrm{C}$, as recorded by the nearby weather stations located at Galtür (Austria, $1589 \mathrm{~m}$ a.s.l.) and Scuol (Switzerland, $1253 \mathrm{~m}$ a.s.l.), respectively (Bauerochse and Katenhusen, 1997). The Fimba Valley is located north of the Silv retta Alpine ridge and joins the lower lying Paznaun Valley at the village of Ischgl (Austria). Because of historical land use and legacy reasons, the northern and lower parts of the Fimba Valley belong to

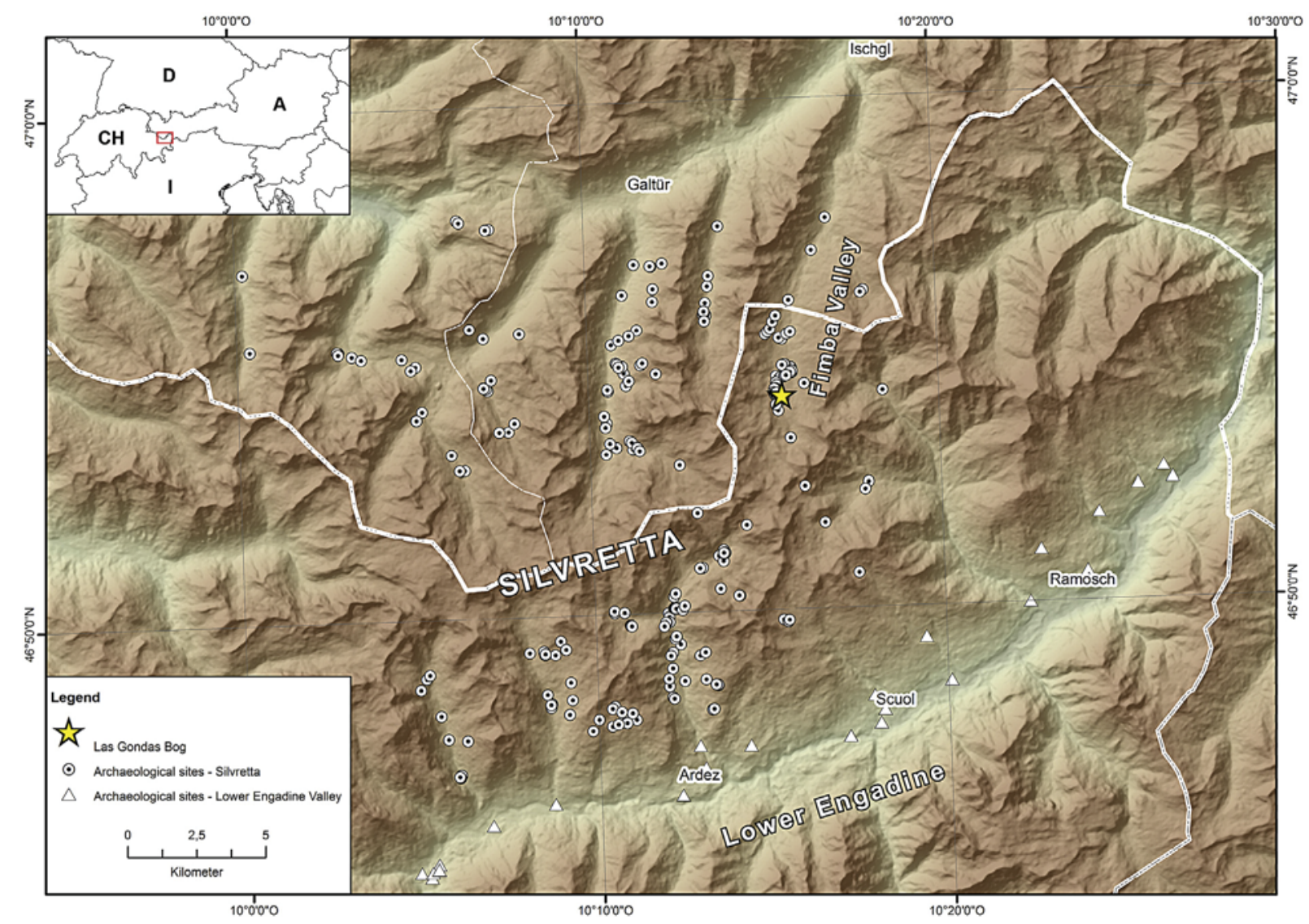

Fig. 1. Location of the Silvretta Massif and Fimba Valley in the Eastern Alps (Switzerland/Austria) and location of known archaeological sites of the Silvretta Massif (above $1500 \mathrm{~m}$ a.s.l., circles) and of the Lower Engadine (below 1500 m a.s.l., triangles). The star marks the location of the Las Gondas Bog. Source Digital Terrain Model: ASTER GDEM (ASTER GDEM is a product of METI and NASA). Source country-borders: http://diva-gis.org/gdata. 
Austria, while the southern uppermost parts belong to Switzerland. The Las Gondas Bog (Fig. 2) is located in the upper Swiss part of the Fimba Valley, at 46.902083 N, 10.257277 E (2363 m a.s.l.), where it is neighbored by several archaeological sites (Fig. 3).

\section{Material and methods}

\subsection{Palynology}

A $177 \mathrm{~cm}$ long peat core was extracted from the Las Gondas Bog in 2008 with the help of a $50 \mathrm{~cm}$ long Russian peat corer of $5 \mathrm{~cm}$ width. The core was thereafter stored in a cold chamber (at $4{ }^{\circ} \mathrm{C}$ ) until sample preparation and chemical treatment. Fifty eight sediment samples of $1 \mathrm{~cm}^{3}$ each were taken along the peat core every $4 \mathrm{~cm}$ and at $1 \mathrm{~cm}$ resolution from 54 to $37 \mathrm{~cm}$ depth due to high compaction of the sediment (see below). Each sample received a defined number of Lycopodium clavatum spores for calculation of palynological concentration and influx (Stockmarr, 1971; Maher, 1981). The sediment fractions $7-150 \mu \mathrm{m}$ were chemically pre pared following the protocol by Seiwald (1980), and by using a chlorification step, 1 min acetolysis, as well as hydrofluoric acid (concentration 10\%, warm, to remove silt), and a final staining with fuchsine in glycerine. Pollen and spores were quantified using an Olympus BX50 light microscope at $\times 400$ magnification (including phase contrast) and were identified according to the reference collection of the Institute of Botany, University of Innsbruck and the literature (Moe, 1974; Punt, 1976; Punt and Clarke, 1980, 1981, 1984; Punt et al., 1988; Punt and Blackmore, 1991; Reille, 1992; Fægri et al., 1993; Beug, 2004). At least 500 tree pollen were counted for each sample, except for the samples at 151 and $27 \mathrm{~cm}$ depth, where 212 and 389 tree pollen were counted, respectively, because of low pollen abundance. Pollen of Pinus mugo, Pinus sylvestris type and undefined pine pollen are gathered among the taxa Pinus. Alnus glutinosa type and Alnus viridis were not distinguished from each other. However, most Alnus pollen counted belonged to Alnus viridis (syn. Alnus alnobetula) throughout the Las Gondas stratigraphy. Cerealia type refers to Poaceae pollen larger than $40 \mu \mathrm{m}$, and were determined according to morphological characteristics (Beug,
2004; Colombaroli et al., 2013). Micro charcoals (size class 7$150 \mu \mathrm{m}$ ) were identified as black, angular, and opaque particles (Swain, 1973; Patterson et al., 1987) and counted on the same palynological slides and calculated compared to the sum of terrestrial pollen taxa, excluding Cyperaceae, or as influx values (see below). NPPs were identified in parallel to pollen counting using available literature (e.g. van Geel et al., 2003; van Geel and Aptroot, 2006; Cugny et al., 2010). NPP nomenclature follows cur rent common rules (Miola, 2012) with the abbreviations HdV xxx (Hugo de Vries Laboratory, University of Amsterdam, Amsterdam, The Netherlands), for the according laboratory that described them first. Unidentified and potentially new NPP types were named as IIB 10xx (IIB for Innsbruck Institute for Botany, University of Inns bruck, Innsbruck, Austria).

\subsection{Chronology}

Ten radiocarbon dates were obtained along the peat core using plant macroremains. Samples were pre treated to remove potential young and old contamination with carbonates and humic acids (Hajdas, 2008). The AMS analyses were performed at the ETH Zürich, Switzerland, using the dedicated system of MICADAS (Synal et al., 2007). The ${ }^{14} \mathrm{C}$ ages were calculated according to Stuiver and Polach (1977), calibrated using the software clam (Blaauw, 2010; version 2.1) and the INTCAL09 calibration curve (Reimer et al., 2009), and drawn using the package ggplot2 (Wickham, 2009; version 0.9.3.1) within the statistical software $R$ (R Core Team, 2013; version 3.0.2). The calibrated ages are reported in calendar years before present (i.e.

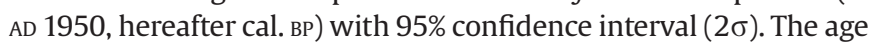
depth model was drawn using linear interpolation between cali brated dates and the surface date (AD 2008 coring).

\subsection{Data presentation}

The palynological diagrams of the relative occurrence and influx of selected pollen, spores, and NPPs were drawn using the software Tilia (Grimm, 2011, 2013; versions 1.7.16 and 2.0.4, respectively). All taxa were expressed as a percentage of the sum of terrestrial pollen

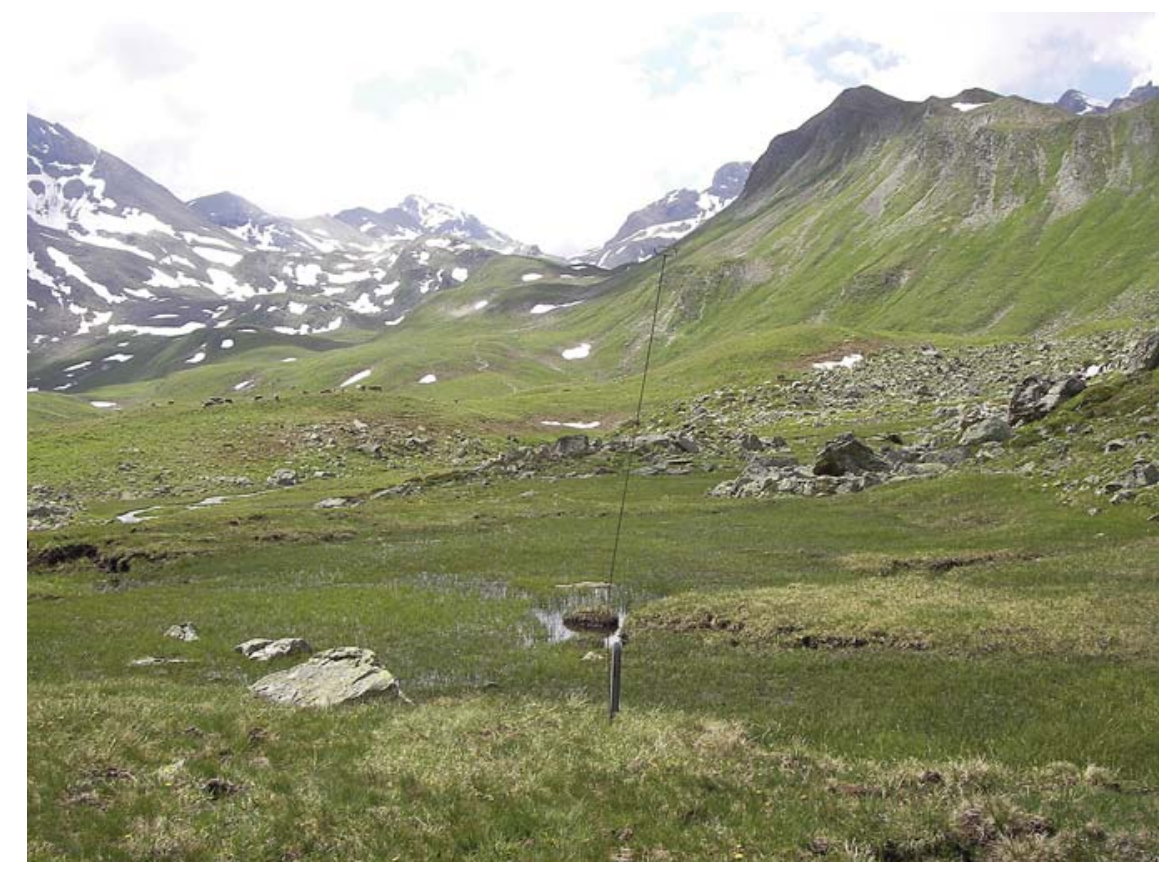

Fig. 2. Photograph of the Las Gondas Bog and the AD 2008 coring location (in the center) in the upper Fimba Valley, Switzerland (Photography: Irina Anich, 2011). 
taxa (excluding Cyperaceae). Influx amounts are expressed as microfossils. $\mathrm{cm}^{-2} \cdot \mathrm{y}^{-1}$. Local pollen assemblage zones (LPAZ) were distinguished by CONISS clustering (stratigraphically constrained incremental sum of squares, Grimm, 1987), using a square root transformation of terrestrial pollen taxa percentages. The relevant number of zones to consider was ascertained according to the broken stick model (MacArthur, 1957; Bennett, 1996), with the help of the package rioja (Juggins, 2012; version 0.8 5), within the software $R$ (R Core Team, 2013; version 3.0.2) and with the same clustering method. The zones were incrementally numbered from the oldest to the newest, and sub zones were distinguished by letters (i.e. $a, b$ ). The entire palynological dataset will be stored at the European Pollen Database (EPD) in due time.

\section{Results}

\subsection{Chronology of the Las Gondas Bog stratigraphy}

The radiocarbon dates (Table 1 ) and the corresponding age depth model (Fig. 4a) reveal that the sedimentation of Las Gon das peat started at about 10,450 cal. BP. Thus, the peat stratigraphy records most of the Holocene vegetation development. The bog grew at an accumulation rate of $25-44 \mathrm{y} . \mathrm{cm}^{-1}$ during the first part of the Holocene (to ca. $6400 \mathrm{cal}$. вP). Thereafter, the accumulation rate was $115 \mathrm{y} . \mathrm{cm}^{-1}$ for about 900 years (Fig. 4b). It was followed by a phase of very slow peat growth until $2200 \mathrm{cal}$. BP $\left(310 \mathrm{y} . \mathrm{cm}^{-1}\right)$, visible already during coring in the field as highly compacted, finely laminated peat from 48 to $37 \mathrm{~cm}$ (Figs. 4 and 5). Finally, for the last

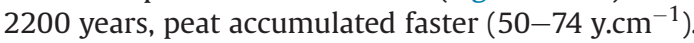

\subsection{Flora and vegetation development}

Within the 58 peat samples, 102 pollen and spores taxa and 142 NPP taxa were identified, including 60 NPPs potentially described for the first time for alpine and subalpine environments (some are shown on Fig. 6). The most relevant taxa are major tree taxa, herb taxa indicating human impact, pasture and grazing (Fig. 7), as well as spores from coprophilous fungi and micro charcoal particles (Fig. 8). The palynological samples were sorted by the CONISS clustering method according to their terrestrial pollen assemblages. The resulting classification and the broken stick model suggest the existence of four local pollen assemblage zones (LPAZ 1-4, with two sub zones in each of the first three main zones).

\subsubsection{LPAZ 1 (177-113 cm, 10,450-8300 cal. BP)}

The peat sedimentation of the Las Gondas Bog started at about $10,450 \mathrm{cal}$ вр. The first local pollen assemblage zone was charac terized by important proportions of arboreal pollen taxa (90-95\% of the pollen sum), mainly represented by high pollen values of
Pinus cembra (also present as needles, Anich, 2013), Pinus (mainly Pinus mugo), Corylus avellana, as well as by high values of Cyper aceae and the unknown NPP type IIB 1034 (Figs. 6-8). Ulmus was found in amounts higher than $1 \%$ (and up to $6.8 \%$ at $10,200 \mathrm{cal} \mathrm{BP}$ ) exclusively during this zone. The first sub zone LPAZ 1a (10,450$9300 \mathrm{cal} \mathrm{BP}$ ) exhibited the highest records of Corylus avellana (39\%) of the entire stratigraphy around 10,070 cal вp, as well as a micro charcoal particles peak at $\mathrm{ca} .9700 \mathrm{cal}$. Bp. Relatively high values of spores of Sordariaceae, Cercophora, Gaeumannomyces, Micro thyrium, Meliola and Valsaria variospora (HdV 140, van Geel et al., 1983, Fig. 6) were found, and Volvocaceae (HdV 128B) were pre sent almost exclusively during this sub zone (Fig. 8). The second sub zone LPAZ 1b (9300-8300 cal BP) differed from LPAZ 1a by decreasing Pinus, Corylus and Cyperaceae values, and by some tree taxa that reached slightly higher amounts, namely Picea abies, Abies alba, Tilia, and Betula (Fig. 7). As reaction to the tree cover decline, Poaceae, Apiaceae, Thalictrum and Ranunculus acris type increased. Micro charcoal particles were found less often, and the amoebozoa Arcella and Centropyxis appeared for the first time (Fig. 8).

\subsubsection{LPAZ $2(113-53.5 \mathrm{~cm}, 8300-6300 \mathrm{cal}$. вP)}

The second zone was characterized by steady amounts of Pinus and consistently high values of Pinus cembra (higher than 5\%, except for ca. 7600-7300 cal вP, Fig. 7). Some NPPs, such as sterile fungal stroma (IIB 1048) and conifer wood particles (IIB 1036, probably from Pinus cembra; Fig. 6), were present almost exclu sively during this zone (Fig. 8). The sub zone LPAZ 2a (83007400 cal вр) registered high values of Picea abies and Abies alba (to $25.9 \%$ and $5.7 \%$, respectively). The representation of Salix and Alnus (i.e. Alnus viridis) increased, while the pollen values of Ulmus, Tilia, Betula, and Corylus avellana decreased. Non arboreal taxa (i.e. herbs), were generally less present than in LPAZ $1 \mathrm{~b}$, main con tributors were Apiaceae and $R$. acris type, together with Poaceae (Fig. 7). Less micro charcoal particles were found than in LPAZ 1 and less pollen of Cyperaceae were present (about 30-50\% rela tively to the pollen sum), but higher Selaginella selaginoides values. During LPAZ 2b (7400-6300 cal вP) the highest proportion of Pinus cembra (10.5\%, ca. 7200 cal. BP) are found. Some non pollen paly nomorphs presented their highest values almost exclusively during LPAZ 2b (Fig. 8). Some of these NPPs are spores from coprophilous fungi (Sordariaceae), loricae of the rotifer Habrotrocha angusticollis (syn. Callidina angusticollis), and the dinoflagellates Peridinium (up to $8.3,44.9$ and $15.8 \%$ compared to the reference pollen sum). The fungus Anthostomella cf. fuegiana was mainly found during this zone, as well as the regulate fungal spore type IIB 1060 (Fig. 6).

\subsubsection{LPAZ $3(53.5-24 \mathrm{~cm}, 6300-1600 \mathrm{cal} . \mathrm{BP})$}

The LPAZ 3 is characterized by decreasing pollen values of Pinus and Pinus cembra, and increasing Picea abies and Alnus (up to

Table 1

Radiocarbon dates obtained on terrestrial plant macrofossils from the Las Gondas peat bog stratigraphy (LGF-2008-1), Fimba Valley, Switzerland. AMS analyses were

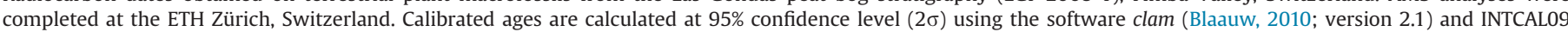
calibration curve of Reimer et al. (2009), within the statistical software $R$ (R Core Team, 2013; version 3.0.2).

\begin{tabular}{|c|c|c|c|c|c|c|}
\hline Laboratory number & Depth (cm) & Material & Dry weight (mg) & $\operatorname{Age}^{14} C_{B P}$ & $\delta^{13} \mathrm{C}$ & Age cal. BP (AD 1950, 2б) \\
\hline ETH-44678 & 17.718 .5 & Substantia lignosa & 9 & $1355 \pm 40$ & $-26.1 \pm 1.1$ & $1261 \pm 80$ \\
\hline ETH-44679 & $36.5 \quad 37.5$ & Substantia lignosa & 5 & $2220 \pm 30$ & $-24.8 \pm 1.1$ & $2241 \pm 89$ \\
\hline ETH-45937 & $47.5 \quad 48.5$ & Bryophytes stems indet. & 12 & $4910 \pm 45$ & $-28.9 \pm 1.1$ & $5658 \pm 71$ \\
\hline ETH-43805 & $54.5 \quad 55.5$ & Roots, Prothalium indet. & 2 & $5670 \pm 55$ & $-11.8 \pm 1.1$ & $6471 \pm 155$ \\
\hline ETH-45238 & $61.5 \quad 63.5$ & Substantia lignosa & 1 & $5875 \pm 35$ & $-25.6 \pm 1.1$ & $6680 \pm 105$ \\
\hline ETH-43804 & 86.587 .5 & Pinus periderm, Substantia lignosa & 4 & $6535 \pm 35$ & $-26.8 \pm 1.1$ & $7448 \pm 110$ \\
\hline ETH-43803 & 102.5103 .5 & Rhizome of Cyperaceae & 3 & $7020 \pm 40$ & $-27.9 \pm 1.1$ & $7852 \pm 93$ \\
\hline ETH-43074 & $129.5 \quad 130.5$ & Substantia lignosa & 10 & $8105 \pm 50$ & $-24.7 \pm 1.1$ & $9023 \pm 233$ \\
\hline ETH-43073 & $158.5 \quad 159.5$ & Substantia lignosa & 7 & $8850 \pm 50$ & $-27.6 \pm 1.1$ & $9953 \pm 215$ \\
\hline ETH-43072 & $174.5 \quad 175.5$ & Substantia lignosa & 10 & $9240 \pm 55$ & $-24.9 \pm 1.1$ & $10,406 \pm 150$ \\
\hline
\end{tabular}




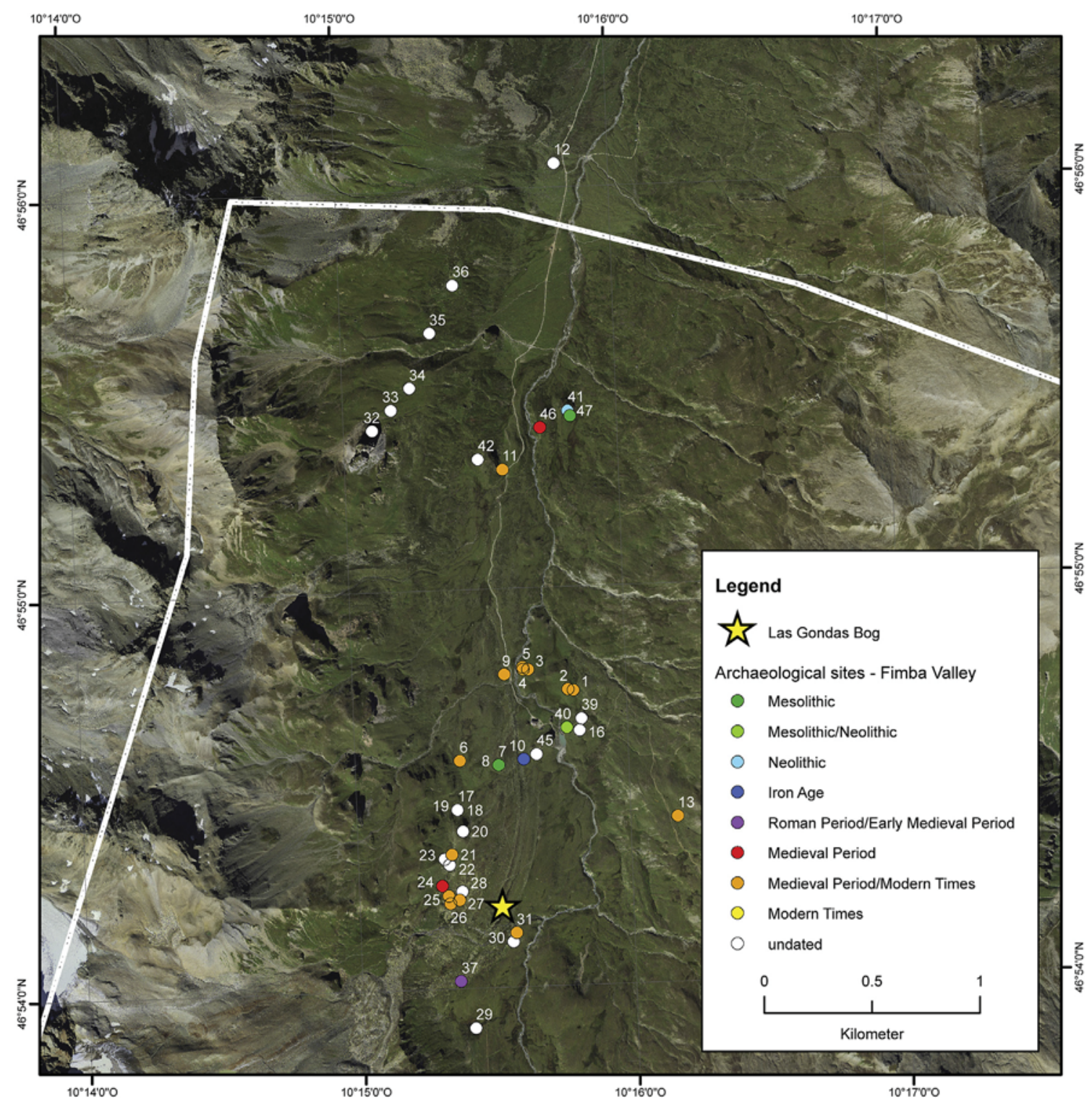

Fig. 3. Location of Las Gondas Bog (star) in the Fimba Valley, Switzerland/Austria, with the 42 dated archaeological sites in the nearest surroundings, sorted by different periods (Mesolithic to Modern Times). Source orthophoto: ${ }^{\circledR}$ SWISSTOPO Bundesamt für Landestopografie. Source country-borders: http://diva-gis.org/gdata.

30.0 and $29.1 \%$, respectively, Fig. 7). In parallel, herb and fern taxa such as $R$. acris type, Poaceae, Campanula/Phyteuma type and Asteraceae (including Cichorioideae), as well as Pteridium aquili num, Botrychium type, and monolete fern spores increased. In LPAZ 3a (6300-4250 cal вP) a more diversified range of open landscape and pastoral indicators was found (such as Chenopo diaceae, Urtica and Artemisia), as well as the first continuous occurrence of cereal pollen. This sub zone also showed a notable decline (or disappearance) of NPPs (Fig. 8). During LPAZ 3b (4250-1600 cal вр), tree pollen percentages decreased strongly to a total of 64\% (Fig. 7), mostly because of the decrease of Pinus (to $15.7 \%$ ), and in spite of the importance reached by Alnus (to 29.1\%). Consequently, herb taxa reached high proportions, mostly due to Poaceae, Asteraceae and Cichorioideae (to 21.5, 2.9 and 4.9\%), but also due to some pastoral, cultural and open landscape indicators, which showed continuous signals, such as Cerealia type, Plantago (several taxa), Rumex acetosella type, Artemisia, and R. acris type (to $0.8,1.7$, and 2.4\%). Micro charcoal particles and Cyperaceae were found again in higher values, as well as Corylus avellana
(6.7\%) around 1730 cal вр (Fig. 7). Additionally, several zoological NPPs, namely Arcella, H. angusticollis, Gyratrix hermaphroditus and Microdalyellia armigera appeared again after a period of lower occurrences (Fig. 8). The same accounted also for Valsaria vari ospora (Fungi) and Zygnema (Algae), whereas Macrobiotus (Tar digrada) and Difflugia rubescens (Rhizopoda) showed up for the first time in higher values (Fig. 8).

\subsubsection{LPAZ 4 (24-0 cm, $1600 \mathrm{cal}$. BP - AD 2008)}

The last zone was characterized by a low proportion of tree pollen ( $43-68 \%)$, mainly due to a reduction of Picea abies and the increase of pastoral and cultural indicators such as Cerealia type, Secale cereale, Urtica, $R$. acetosella type, Artemisia and $R$. acris type (Fig. 7). Cichorioideae, Poaceae and Apiaceae increased as well. Modern Times (since AD 1500) can be set apart from the Medieval Period by the decrease of Secale cereale and important proportions reached by coprophilous fungi (Fig. 8) such as Sordariaceae, Cercophora and Sporormiella (up to 3.2, 5.6 and 55.0\% of the pollen sum). 

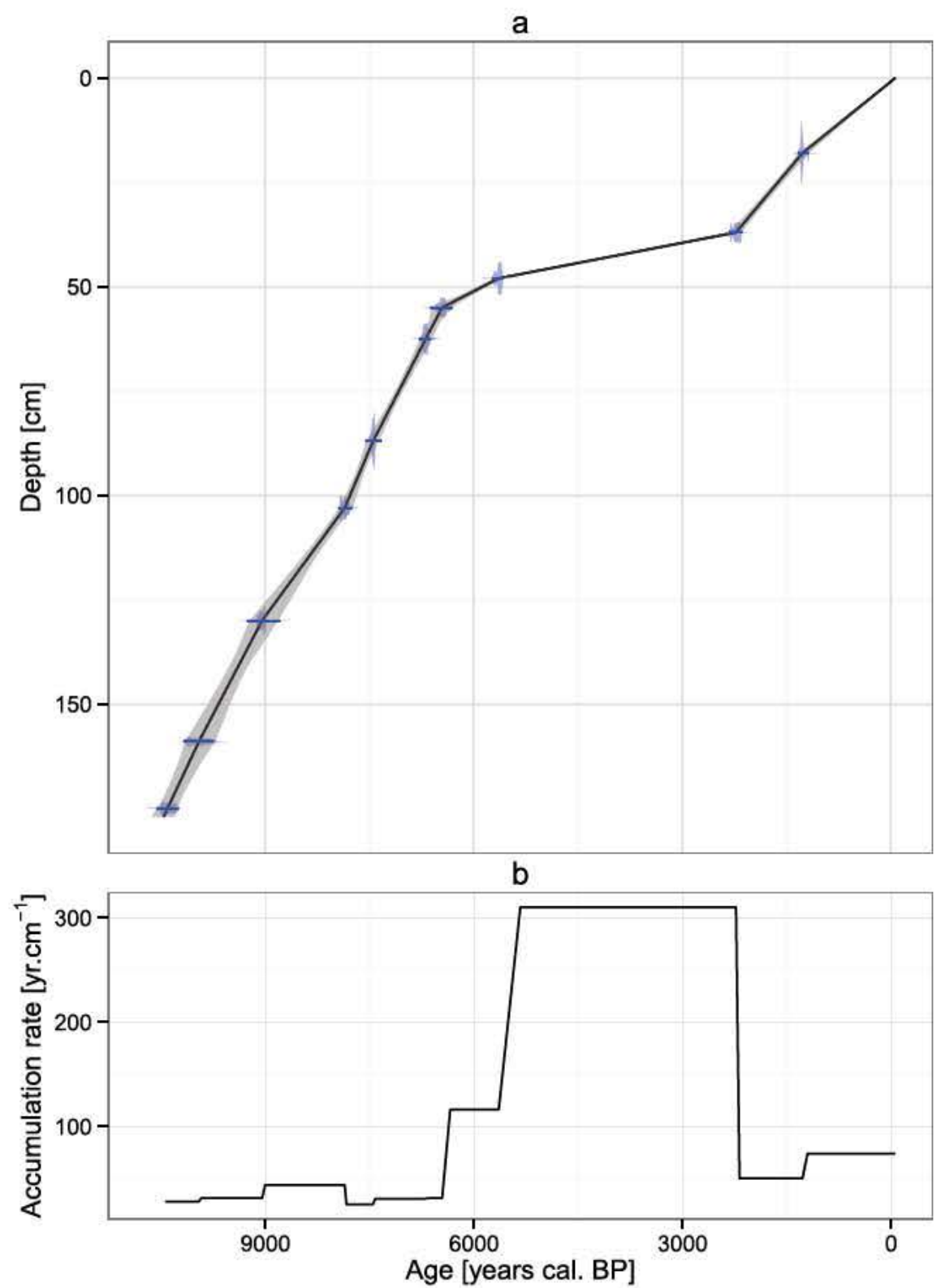

Fig. 4. Age-depth model (a) and accumulation rate (b) of the Las Gondas peat bog stratigraphy (LGF-2008-1), Fimba Valley, Switzerland, based on ten AMS radiocarbon dates (see Table 1). Chronological calibration was done using the software dam (Blaauw, 2010; version 2.1) and by using the calibration curves of Reimer et al. (2009).

\section{Discussion}

\subsection{Climatic impact on the vegetation composition}

5.1.1. Effect of climate variations on the location of the timberline The treeline ecotone results from an equilibrium affected by both climatic and anthropogenic factors. It is known to be highly

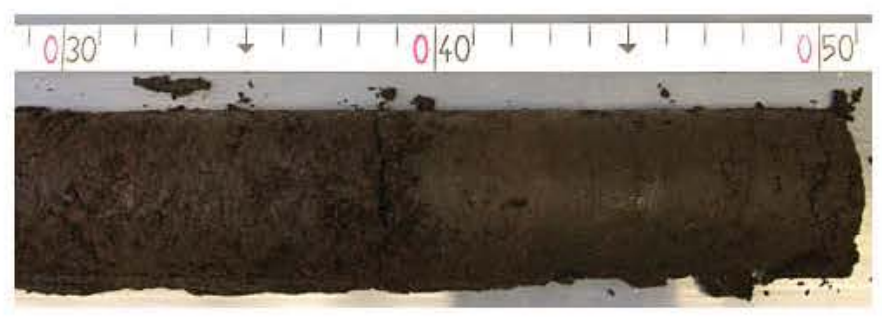

Fig. 5. Photograph of the lower half ( $3050 \mathrm{~cm}$ ) of the peat core LGF-2008-1, from the Las Gondas Bog. A heavy compaction of the sediment is visible from 48 to $37 \mathrm{~cm}$. sensitive to temperature changes (Körner, 1998; Tinner and Kaltenrieder, 2005). The first two major changes in the pollen as semblages of the Las Gondas Bog sediment revealed by the clus tering classification of samples (Fig. 7) coincide with known cold climatic phases. First, the transition from LPAZ 1 to LPAZ 2 $(8300 \mathrm{cal}$. вP) can be linked to the so called $8.2 \mathrm{ka}$ cold event (Haas et al., 1998; Tinner and Lotter, 2001). Second, the transition from LPAZ 2 to LPAZ 3 ( $6300 \mathrm{cal}$. BP) is synchronous with the Rotmoos 1 climatic deterioration (Bortenschlager, 1970; Magny et al., 2006). This concomitance between climatic phases and the statistical definition of LPAZ changes suggests a direct effect of climatic factors on the local vegetation. In this respect, the $8.2 \mathrm{ka}$ cold event and the subsequent oceanic climatic conditions (cf. Tinner and Lotter, 2001) may have favored the growth of Pimus cembra at timberline and Picea abies and Abies alba (both below $2000 \mathrm{~m}$ a.s.l.), and may have been responsible for the strong and rapid decrease of Corylus avellana and Ulmus in the surrounding valleys (Fig. 7). Later, Pinus mugo and Pinus cembra stands were 


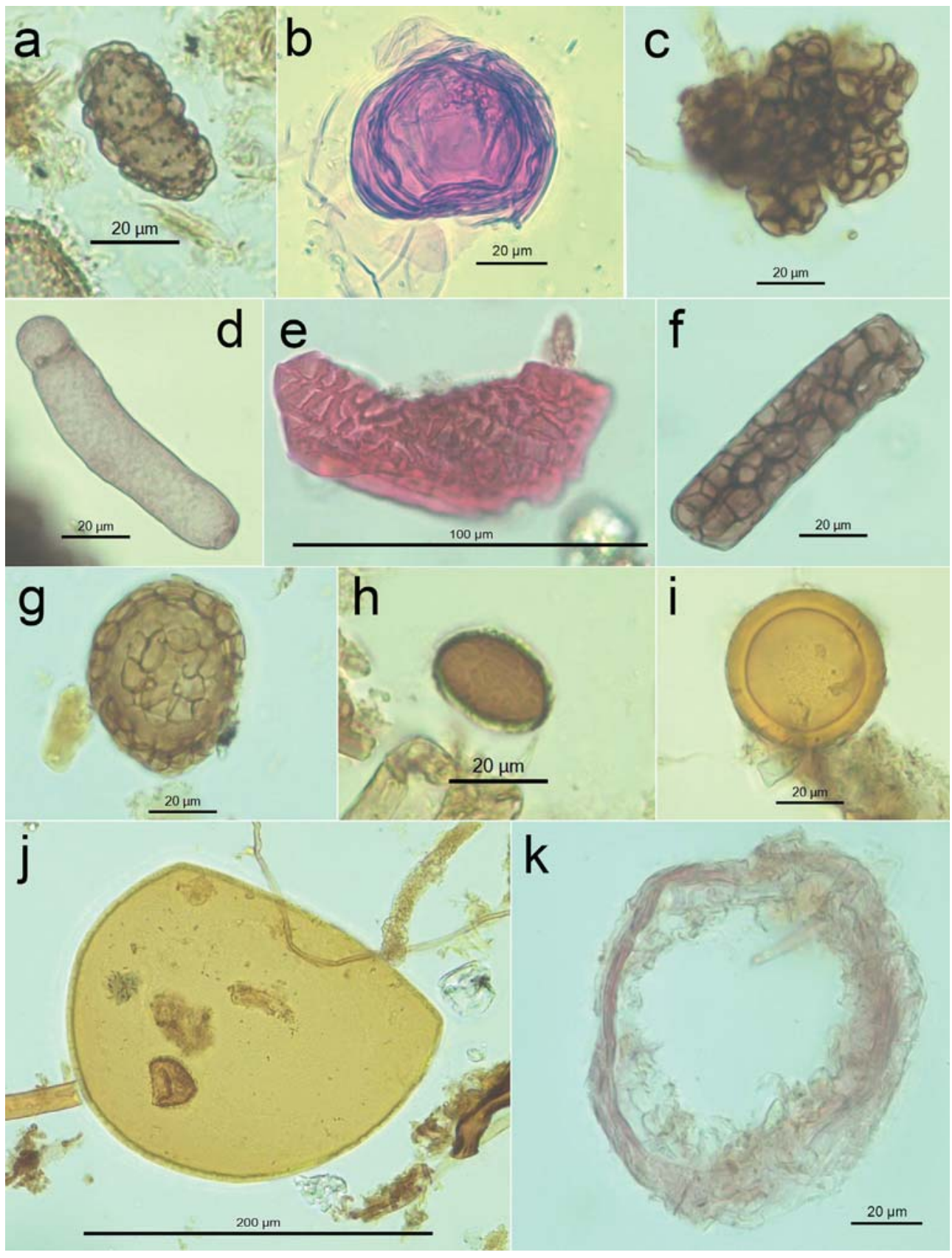

Fig. 6. Photograph of selected and potentially novel non-pollen palynomorphs for alpine areas. a. Valsaria variospora (HdV-140), b. Peridinium (Dinoflagelatta), c. IIB-1029 (sterile fungal stroma), d. IIB-1034 (indet.), e. IIB-1036 (conifer wood particle, $c f$. Pinus cembra), f. IIB-1047 (sterile fungal stroma), g. IIB-1048 (sterile fungal stroma, cf. TM-4034), h. IIB-1060 (indet. fungal spore rugulate), i. IIB-1064 (indet), j. IIB-1063 (cf. Cladocera valve), k. IIB-1057 (root indet. cross section).

replaced by Alnus (mainly Alnus viridis). This is in agreement with other studies (e.g. Veski et al., 2004; Kofler et al., 2005; Tinner and Lotter, 2006; Finsinger and Tinner, 2007), and particularly with the one undertaken by Bauerochse and Katenhusen (1997) at the same bog location.

In parallel to these major changes that directly affected the presence and survival of species on a local level, climatic events also affected the quantitative representation of taxa. A decline of rela tive Pinus values after 9700 cal. BP (probably related to a reduction in locally growing Pinus mugo) is also indicated by the synchronous decline of Pinus influx values below 200 pollen.cm ${ }^{-2} \cdot \mathrm{y}^{-1}$ (Fig. 9), followed by a general decline of conifers since 9300 cal. BP (Figs. 7 and 9). This massive Pinus decline is in line with the evidence presented by Tinner and Kaltenrieder (2005) for the Swiss Central Alps. Thereafter, Betula reached its maximum occurrence between ca. 9200 and 8400 cal. BP as pioneer species (Fig. 7), meaning that the landscape became more open, as also shown by an expansion of Poaceae and Apiaceae (also indicated by influx values, Fig. 9; LPAZ 1b). Later, Pinus cembra values increased to more than $5 \%$ from $c a$. 8200 to 5650 cal. BP (except around ca. 8030, from ca. 7600 to 7300 , and around 6000 cal. BP), and with values up to $10.5 \%$ around 7200 cal. вp (Fig. 7). This local presence of Pinus cembra is confirmed by according rises in influx values (Fig. 9). The highly significant Pearson's correlation coefficient (0.63) between Pinus cembra and Salix influx values (Fig. 9) suggests Salix shrubs to have been pre sent in the understory of the Pinus cembra forest at that time. After 


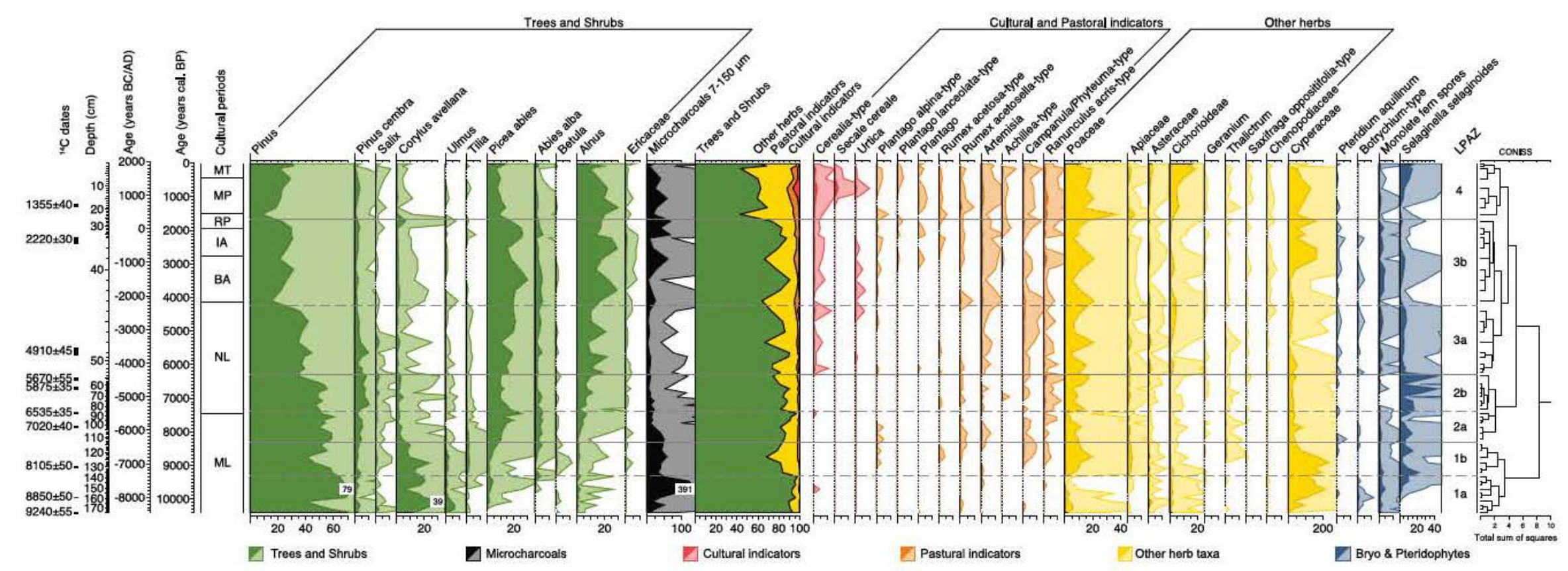

Fig. 7. Synthetical palynological diagram, time linear, of selected taxa from Las Gondas Bog, Fimba Valley, Switzerland, comprising pollen and cryptogam spores. Taxa are expressed as percentages compared to the pollen sum, made out of terrestrial plants, excluding Cyperaceae. The diagram was drawn using the software Tilia (Grimm, 2011; version 1.7.16). Unless otherwise noted, main tick marks represent 10\%. Light color curves result from a tenfold exaggeration of the original curves. Cultural periods are ML: Mesolithic, NL: Neolithic, BA: Bronze Age, IA: Iron Age, RP: Roman Period, MP: Medieval Period, MT: Modern Times. 


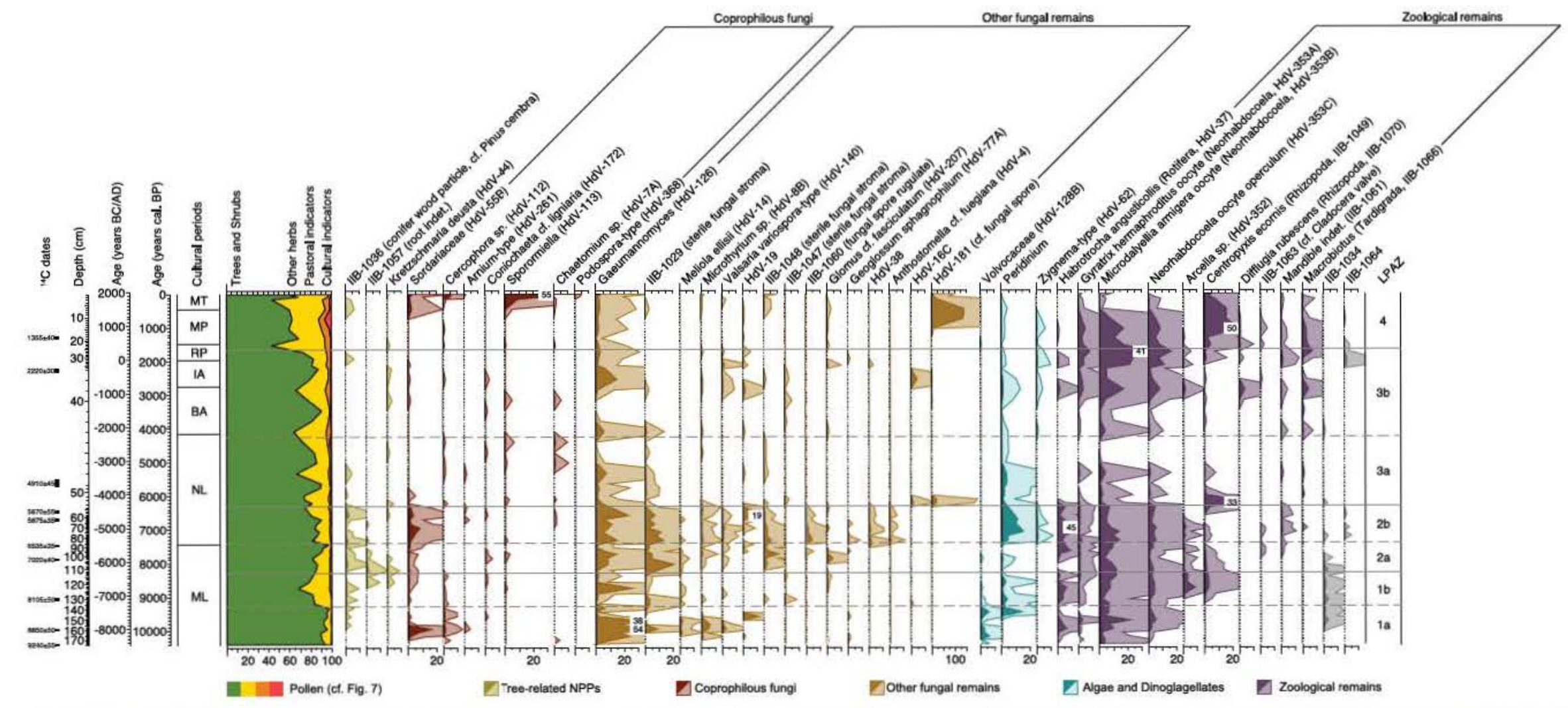

Fig. 8. Synthetical diagram, time linear, of selected non-pollen palynomorphs from Las Gondas Bog, Fimba Valley, Switzerland. Taxa are expressed as percentages compared to the pollen sum. The diagram was drawn using the software Tilia (Grimm, 2011: version 1.7.16). Unless otherwise noted, main tick marks represent 10\%. Light color curves result from a tenfold exaggeration of the original curves. Cultural periods are ML: Mesolithic, NL: Neolithic, BA: Bronze Age, IA: Iron Age, RP: Roman Period, MP: Medieval Period, MT: Modern Times. 


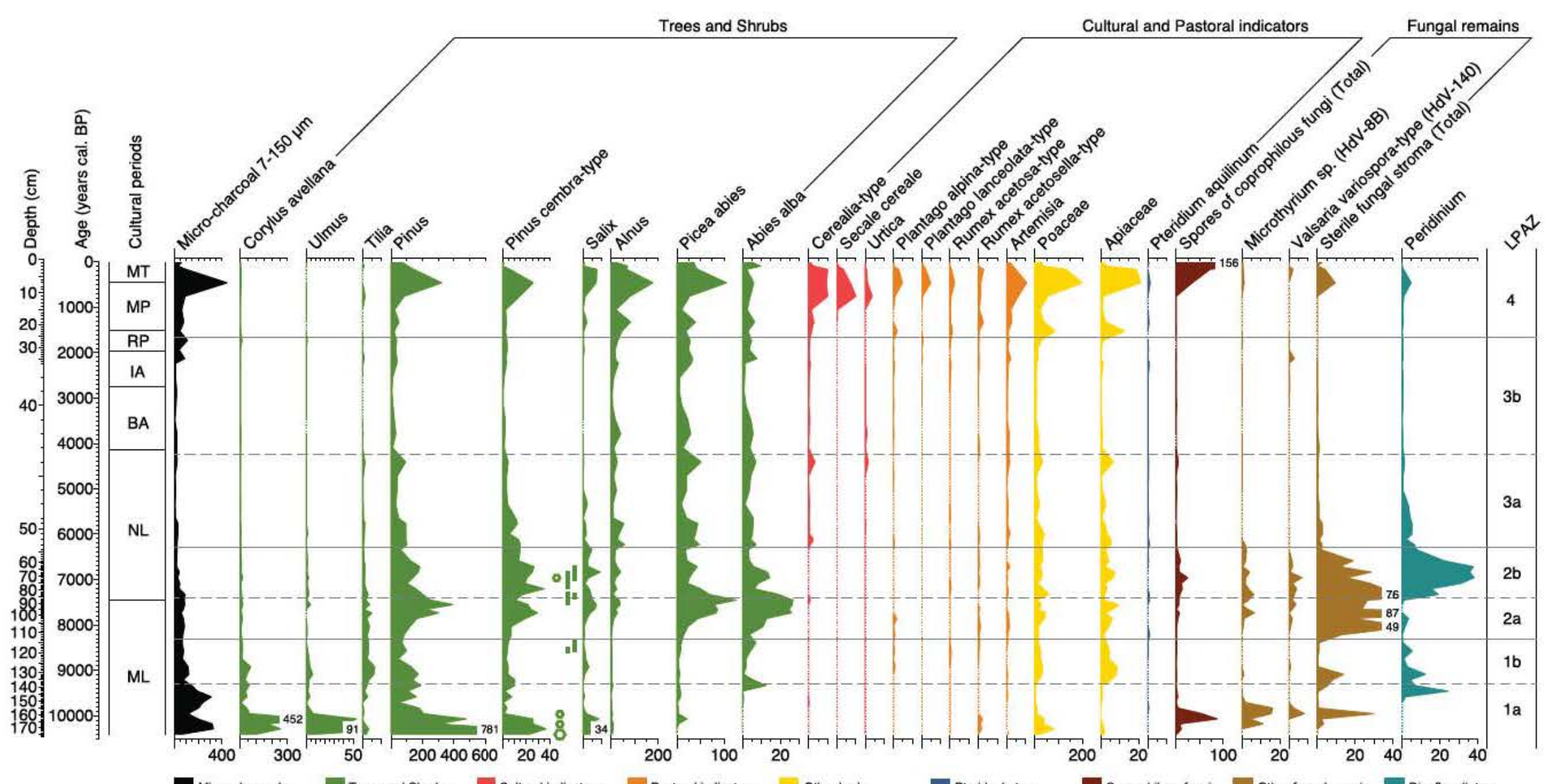

Fig. 9. Influx diagram of selected taxa from Las Gondas Bog, Fimba Valley, Switzerland, expressed as microfossils.cm ${ }^{-2}$.year ${ }^{-1}$. Beside the curve of Pinus cembra, bars show age ranges of dendrochronologically dated Pinus cembra stems found in the Las Gondas Bog peat (Nicolussi, 2012), and hexagons show macrofossil finds (needles) of Pinus cembra (Anich, 2013). The diagram was drawn using the software Tilia (Grimm, 2013; version 2.0.4). Unless otherwise noted, main tick marks represent 10 microfossils.cm ${ }^{-2}$.year ${ }^{-1}$. Cultural periods are ML: Mesolithic, NL: Neolithic, BA: Bronze Age, IA: Iron Age, RP: Roman Period, MP; Medieval Period, MT: Modern Times. 
5500 cal. BP, Pinus cembra showed an important and steady decline towards extant values lower than 1\%, representing today's Pinus cembra populations at around $2000 \mathrm{~m}$ a.s.l. in the Fimba Valley, $c a$. $400 \mathrm{~m}$ below the former natural Pinus cembra timberline.

Extraordinarily, several Pinus cembra tree stems were found within the Las Gondas Bog peat (Bauerochse and Katenhusen, 1997; Nicolussi, 2012; Remy, 2012). Six of them were dendrochronologi cally dated, and revealed the presence of adult trees around the bog from 8615 to 8344 cal. BP, and from 7554 to 6692 cal. BP (Nicolussi, 2012). During these periods, pollen of Pinus cembra reached values from 2.2 to $3.4 \%$, and from 2.2 to $10.5 \%$ of the pollen sum, respec tively. Influx values of Pinus cembra ranged from 3.9 to 4.6 pol len. $\mathrm{cm}^{-2} \cdot \mathrm{y}^{-1}$ for 8615 to $8344 \mathrm{cal}$. BP, and from 10.6 to 35.1 pollen. $\mathrm{cm}^{-2} \cdot \mathrm{y}^{-1}$ for 7554 to 6692 cal. вр (Fig. 9). In addition, macrofossil findings of Pinus cembra needles in the lowermost peat samples show that this tree was locally present already during the Early Holocene, around 10,400 cal. вр (Anich, 2013). However, following recommended threshold values relying on influx and percentage values (Tinner et al., 1996; Wick and Tinner, 1997; van der Knaap et al., 2001; Tinner and Theurillat, 2003; Kaltenrieder et al., 2005; Tinner, 2007; Ejarque et al., 2010; Lisitsyna et al., 2011), the influx values of Pinus cembra lower than 35 pollen. $\mathrm{cm}^{-2} \cdot \mathrm{y}^{-1}$ at Las Gondas Bog (Fig. 9) would not indicate the local presence of the tree. Nevertheless, and even if the pollen produc tion might have been low eventually because of genetic differences, microclimatic conditions or the short vegetation period and extreme environment at $2400 \mathrm{~m}$ a.s.l., the dendrochronologically dated Pinus cembra stems found within the peat, as well as the needles and periderm parts found (IIB 1036, Fig. 6) clearly point at extensive stands of Pinus cembra around the Las Gondas Bog, above $2370 \mathrm{~m}$ a.s.l., from $\mathrm{ca}$. 10,400 to $5000 \mathrm{cal}$. BP, at least during several centennially long, climatically favorable warm humid periods (Haas et al., 1998). This implies that an open forest and timberline ecotone with at least scattered trees would have been located around or above $2370 \mathrm{~m}$ a.s.l. from the Mesolithic Period onwards and during most of the Neolithic Period. From ca. 7600 cal. вP on wards, a rise in Alnus (i.e. Alnus viridis, as also shown by macrofossil finds, cf. Anich, 2013), and of Picea abies and Salix occurred, both in relative and influx pollen values (Figs. 7 and 9). This rise in Alnus viridis and Picea abies might be related to the Central European cold/humid climatic phase CE 4 (dated to ca. 7450-7050 cal. вр, Haas et al., 1998). In parallel, the values (relative and influx) of Peridinium and Valsaria variospora rose after 7500 cal. BP, and sus tain such an interpretation of more humid conditions.

\subsubsection{A Drought period 5300-2850 cal. вP in the Silvretta Alps}

The age depth model from the Las Gondas Bog revealed a period of highly compacted peat, with a slow growth of the bog, between ca. 5300 and 2850 cal. BP (Fig. 4b). The compaction was visible during coring fieldwork, showing a nearly micro laminated struc ture of the peat (Fig. 5). None of the plant and cryptogam taxa had a specific response during this period, but some NPPs did respond in a particular way. Most of the NPPs present (Fig. 8) were found in important proportions (relatively to the pollen sum) from the Early Holocene onwards and up to 6300 cal. BP (i.e. during LPAZ 1 and 2). These taxa (as for example Gaeumannomyces, Arcella, H. angusti collis, Gyratrix hermaphroditus, Microdalyellia armigera, and Peri dinium) all need water to develop. During LPAZ 3a (6300-4250 cal. BP) most of them strongly decreased or disappeared, before reap pearing towards the end of this local drought phase around 2850 cal. Bp. Their strong decrease or disappearance, in parallel to the low accumulation rate of the Las Gondas peat, suggests a long lasting local to regional dry period from ca. 5300 to $2850 \mathrm{cal}$. BP. This might be a regional phenomenon as the same reduction of a bog growth can be noticed for more or less the same period in the valley of St. Antönien, Switzerland, $35 \mathrm{~km}$ away (Röpke et al., 2011), or it might even be linked to climatic reorganization phenomena in Central Europe (Magny et al., 2006). A regional drought period has therefore to be implied for the subalpine and alpine altitudes of the Silvretta Alps, eventually linked to known warm dry climatic phases during this period (Haas et al., 1998). By contrast, the reappearing of above mentioned NPPs from ca. 2850 to 2300 cal. вP reveals a remoistening of the Las Gondas Bog concomitant to the central European cold period CE 8, which must have been a massive, climatic deterioration in all of Central Europe and the Northern Hemisphere possibly related to reduced solar activity (Haas et al., 1998; van Geel and Berglund, 2000; Magny, 2007).

\subsection{Human presence in the Fimba Valley}

A huge number of archaeological sites starting with the Meso lithic Period are known in the Silvretta Massif and especially in the Fimba Valley (Figs. 1 and 3). A few Mesolithic to Neolithic sites and one relatively large Iron Age Alpine hut (dated to 2760-2340 cal. вр, number 10 on Fig. 3) were located and excavated in the highest part of the Fimba Valley, all within about $2 \mathrm{~km}$ from the Las Gondas Bog (Reitmaier, 2012; Reitmaier et al., 2013). On the other hand, a few sites from the Bronze Age and Roman Period are known regionally, but not in the nearest vicinity of Las Gondas Bog. There, many archaeological sites dating to the Medieval Period and Modern Times are known, however (Fig. 3).

\subsubsection{Evidence of anthropogenic and livestock impact}

Fire incidents are known to have been generated by humans in alpine environments at least since the Neolithic Period (Bortenschlager, 2000; Gobet et al., 2003; Carcaillet et al., 2009; Rey et al., 2013; Schwörer et al., 2014). At Las Gondas Bog, evidence exists for Mesolithic fire events given the high micro charcoal values between 10,300 and 9300 cal. Bp as recorded both in rela tive and influx values (Figs. 7 and 9). A correlation to local human activities is likely, even if no local archaeological sites and no macroscopic charcoal were found for this time period around Las Gondas Bog. These probable local fires, however, had a massive impact on the local Corylus avellana populations in Fimba Valley, as those showed short term and massive reduction.

Thereafter, during the Neolithic Period (7450-4150 cal. вP), the micro charcoal signal remained quite low (Fig. 7), despite the presence of an Early Neolithic fireplace $600 \mathrm{~m}$ away from the Las Gondas Bog (site number 8 on Fig. 3). Interestingly, a general trend of diminishing total tree pollen amounts combined with rising herbs taxa such as Campanula/Phyteuma type, Artemisia and Cichorioideae is recorded during the second part of the Neolithic period (5500-4150 cal. BP), which suggests a slight opening of the landscape, possibly due to small scale livestock grazing.

At Las Gondas, however, Pinus cembra stayed locally present around 2300-2400 $\mathrm{m}$ a.s.l. until the end of the Late Neolithic Period, as revealed by the pollen percentages and influx values (Figs. 7 and 9). Its values decreased thereafter, possibly due to fire impact as revealed by the slightly rising micro charcoal values (Figs. 7 and 9), and as is also known from other alpine sites where regional fire events impacted Pinus cembra on a landscape scale (Tinner et al., 1996; Conedera et al., 2009; Colombaroli et al., 2010; van der Knaap et al., 2012).

The archaeological sites known in the Fimba Valley (Fig. 3) and near surroundings do corroborate these results as they clearly show an anthropogenic and/or livestock movement to higher altitudes during the Bronze and Iron Age, as well as an increased seasonal use of the higher Fimba Valley during the Medieval Period (Fig. 3). LPAZ 3 exhibits in this context an interesting sequence of four pre Roman oscillations of tree pollen amounts. Although the first two 
main shifts towards reduced tree representation around 6300 and $5400 \mathrm{cal}$. вP may well be related with the climatic deterioration phases of Rotmoos 1 and 2, the third one (4400-3800 cal. вP) does not seem related to any continentally known climatic deterioration, and may be seen in an anthropogenic context as also revealed by slightly rising micro charcoal values (Figs. 7 and 9). On the other hand, the next main tree cover reduction (3200-2400 cal. вp) may be related to the massive climatic deterioration known from all over Europe and the Northern Hemisphere peaking at around 2800 cal. вp (Haas et al., 1998; van Geel and Renssen, 1998; van Geel and Berglund, 2000; Magny, 2007). This climatic deterioration with cool and much wetter climate was probably responsible for the reappearance of a high NPP diversity at Las Gondas Bog since 2800 cal. Bp. Later, a massive rise in micro charcoal values (relative and influx) reveals the major impact of local people since the Ro man Age, and especially during High Medieval Times.

\subsubsection{Past animal husbandry and agriculture in the larger Silvretta area}

Grazing activities can be revealed by apophytes or by spores of coprophilous fungi. They are known to be indicators of grazing pressure on a highly local scale because of their strict ecological requirements (dung deposits) and low dispersal (Innes and Blackford, 2003; van Geel et al., 2003; Blackford and Innes, 2006; Davis and Shafer, 2006; Gauthier et al., 2010; Laine et al., 2010; Dietre et al., 2012). Apart from a first rise in Sordariaceae around 10,000 cal. BP (probably related to coprophilous fungal activity on faeces from wild animals), our fungal dataset indicates one Early Neolithic (from ca. 7300 to 6300 cal. BP) and one historical phase of coprophilous spore peaks (since about $600 \mathrm{cal}$. BP/AD 1350). The Early Neolithic phase comes with a constant presence of $R$. aceto sella type, Artemisa, Poaceae and of $R$. acris type, and might be related to a very first small scale livestock grazing activity in the Fimba Valley even if this apophyte event is very weak. A Neolithic pastoral use of the area would be in line with a Neolithic shelter site excavated at the entrance of the Urschai Valley south west of the Las Gondas Bog (Lower Engadine) dated on charcoal to 64506290 cal. вp (Reitmaier, 2012). This is also in line with the first ev idence of cereal pollen at Motta Naluns (2170 m a.s.l.) above Scuol (Lower Engadine), dated to ca. 6550 cal. BP (Welten, 1982), as well as to the first use of open Larix meadows for pasture at Chanoua (1590 m a.s.l.) near Ardez west of Scuol, at about 5600 cal. Bp (Zoller and Erny Rodman, 1994; Zoller et al., 1996). The growing amounts of alpine pasture and open landscape indicators such as Poaceae, Artemisia, Apiaceae, Asteraceae, Cichorioideae and Campanula/ Phyteuma type, as well as the first occurrence of Chenopodiaceae after 6200 cal. вP is near synchronous to the use of the area mentioned above (Reitmaier, 2012). This suggests the human presence in the Silvretta valleys and their impact on the alpine vegetation. An alternative explanation for the high presence of Sordariaceae between ca. 7300 to $6300 \mathrm{cal}$. BP - showing the complexity of the interpretation of NPP results - could relate to the wood decomposing and saprophytic abilities of Sordariaceae, as during this Neolithic phase, no other spores from coprophilous fungi, especially from those supposed to be more strictly depen dent on faeces (Cercophora, Podospora, Pleospora, and Sporormiella), were present. Given the high amounts of decaying wood of Pinus cembra implied to have been present after 6000 cal. вр (see above), such an interpretation of the Sordariaceae presence cannot completely be excluded. The parallel evolution of Pinus cembra influx values with sterile fungal stroma and with Microthyrium influx values (Fig. 9) - the latter one with a significant Pearson's correlation coefficient of 0.44 - are an additional hint to such decomposition of plant material. Microthyrium pinophyllum regu larly grows on dead pine needles (Ellis and Ellis, 1997).
Later in time, the continuous occurrence of pollen of cereals since ca. 6200 cal. BP at Las Gondas Bog might be related to the human presence in the Lower Engadine Valley, so that cereal pollen was transported by air from lower altitudes, where cereal cultiva tion was possible. Several artifacts (ceramics and arrowheads) were found underneath another rock shelter situation in the Urschai Valley, called Abri Urschai and dated to 4770-4610 and 44504240 cal. BP. This might be linked with the cereal cultivation on the terraces of Plan da Pasa, near Ramosch, less than $12 \mathrm{~km}$ away, dated to $4710-4430$ cal. вP (Reitmaier, 2010, 2012). There, a cereal field terrace management system has been documented archaeologi cally and palynologically from ca. 4200 cal. BP onwards (Zoller et al., 1996; Reitmaier, 2012), which may also have been responsible for the higher cereal pollen values at the Las Gondas Bog around 4200 cal. BP (Figs. 7 and 9). The related changes around Las Gondas Bog (e.g. decrease in Pinus (i.e. Pinus mugo), increase in Alnus (i.e. Alnus viridis), Urtica and Artemisia) are in agreement with research carried out on the Neolithic Period in the Alps (Zoller et al., 1996; Gobet et al., 2003; Finsinger and Tinner, 2006; Haas et al., 2007; Röpke et al., 2011) and other montane areas (Doyen et al., 2013).

Thereafter, strong agricultural activities also occurred during the High Medieval Period, probably with cereal cultivation on both sides of the Silvretta Alpine ridge north and south of the Las Gondas Bog in the Paznaun and Lower Engadine Valleys (up to ca. $1500 \mathrm{~m}$ a.s.l.), where especially Secale cereale was grown, which is known to be one of the main crops cultivated in Central Europe during that time (Behre, 1992). In addition, relatively high values of Artemisia, Plantago, and Rumex taxa sustain such anthropogenic activities around the Silvretta range (Fig. 7), as also shown elsewhere (Kołaczek et al., 2010). We know from historical sources that the upland meadows in the Silvretta, especially those in the northern part of the mountain range, were used from the 11th century AD onwards by people living in the Inn Valley/Lower Engadine (Reitmaier, 2012). In this context, it becomes clear that during the Medieval Period, the Las Gondas Bog sediments also recorded the extensive cereal culture in the lower Paznaun Valley (north of Fimba Valley), apart from the agricultural activities on terraces in the Lower Engadine (south of Fimba Valley and of the Silvretta Alpine ridge). Except for the prehistorical phase discussed above, spores from coprophilous fungi were only present in higher amounts during this Medieval cultural phase. The high amounts of spores of coprophilous Cercophora, Sporormiella, and Sordariaceae therefore reveal the repeated and growing use of the resources of the Fimba Valley as livestock grazing areas during Medieval and Modern Times.

\section{Conclusions}

The data presented here registered the evolution of the vege tation composition of the upper Fimba Valley in the Silvretta Alps regarding two main factors, namely regional Holocene climatic oscillations and the impact of humans and livestock on the local flora and vegetation. Furthermore, our data revealed the local impact of main climatic events on a hemispheric or continental scale such as the cold/humid phases around $8.2 \mathrm{ka}$ and $2.8 \mathrm{ka}$, and the subsequent major vegetation change. Additionally, a severe local to regional drought period was recorded for the time span $5300-2850$ cal. вp by the non pollen palynomorphs evidence in the Las Gondas Bog peat, possibly related to known central European warm dry climatic phases. During some climatic favorable periods (ca. 10,400 cal. вр, and 8600-6700 cal. вр) Pinus cembra populations existed around $2400 \mathrm{~m}$ a.s.l. as indicated by pollen influx values, needles, as well as dendrochronologically dated Pinus cembra tree stems found within the Las Gondas peat. The palynological data demonstrated their utility and their reliability in the context of 
environmental archaeology. Their agreement with archaeological and dendrochronological evidence strengthens previous conclu sions on the climate evolution and human occupation of the Alps and adds to previous palynological studies in the Fimba Valley. This evidence was achieved using typical plant indicators and non pollen palynomorphs, suggesting first human land use and graz ing activities near the timberline since $6200 \mathrm{cal}$. BP, as well as by human impact indicators showing cereal cultivation down in the valley (e.g. the Lower Engadine), and an increased pastoral use of alpine meadows since 4200 cal. Bp. Neolithic to Medieval human and livestock activities had a clear impact on the plant diversity of the alpine vegetation of the Silvretta Massif. Likewise, a vast part of the archaeological sites in the Silvretta Massif remains undated and is likely to permit further comparisons with current and future palaeoecological investigations.

\section{Acknowledgments}

This study is part of the International interdisciplinary research project Climate Change in the Alps - Junior Research Groups/ 10.000 years of climate and settlement dynamics in the Silvretta Massif between the Paznaun (Austria) and Lower Engadine (Switzerland) valleys, and was funded by the Herzog Sellenberg Foundation and the Dr. Erich Ritter Foundation, Germany (reference number: T021/20506/2010). We thank Irina Anich for help in sampling the peat core, Werner Kofler, Daniela Festi and Notburga Oeggl Wahlmüller (University of Innsbruck) for help with the determination of unknown pollen and spores, as well as Bas van Geel (University of Amsterdam), Carole Cugny (University of Toulouse le Mirail), and Walter Gams (The Netherlands) for their kind help in identifying some NPPs. We would also like to thank Andreas Bauerochse and Richard Pott (Germany) for their fasci nating insights into the vegetation of the Fimba Valley. Finally, we are very grateful to two anonymous reviewers and Didier Galop (University of Toulouse le Mirail) for their valuable remarks for the improvement of the manuscript.

\section{References}

Anich, I., 2013. Grossrestanalytische Untersuchung des Las Gondas Moores zur holozänen Floren- und Vegetationsentwicklung im Fimbertal (Schweiz) und Möglichkeiten zur fachdidaktischen Umsetzung des Themas im AHS-Unterricht. Diploma thesis. University of Innsbruck.

Bauerochse, A., Katenhusen, O., 1997. Holozäne Landschaftsentwicklung und aktuelle Vegetation im Fimbertal (Val Fenga, Tirol/Graubünden). Phytocoenologia 27 (3), 353453.

Behre, K.-E., 1981. The interpretation of anthropogenic indicators in pollen diagrams. Pollen et Spores 23, 225245.

Behre, K.-E., 1988. The rôle of man in European vegetation history. In: Huntley, B., Webb III, , Thompson (Eds.), Vegetation History. Handbook of Vegetation Science, vol. 7. Kluwer Academic Publishers, Dordrecht/Boston/London, pp. 633 672 .

Behre, K.-E., 1992. The history of rye cultivation in Europe. Vegetation History and Archaeobotany 1 (3), 141156.

Bennett, K., 1996. Determination of the number of zones in a biostratigraphical sequence. New Phytologist 132 (1), 155170.

Berglund, B.E., Larsson, L., Lewan, N., Olsson, E., Skansjö, S., Riddersporre, M., 1991. The cultural landscape during 6000 years in southern Sweden the Ystad Project. Ecological Bulletins 41. Copenhagen: Mungsgaard.

Beug, H.-J., 2004. Leitfaden der Pollenbestimmung für Mitteleuropa und angrenzende Gebiete. Pfeil, München.

Blaauw, M., 2010. Methods and code for 'classical' age-modelling of radiocarbon sequences. Quaternary Geochronology 5 (5), 512518.

Blackford, J.J., Innes, J.B., 2006. Linking current environments and processes to fungal spore assemblages: surface NPM data from woodland environments. Review of Palaeobotany and Palynology 141 (1), 179187.

Bortenschlager, S., 1970. Waldgrenz- und Klimaschwankungen im pollenanalytischen Bild des Gurgler Rotmooses. Mitteilungen der OstalpinDinarischen Gesellschaft für Vegetationskunde 11, 1926.

Bortenschlager, S., 2000. The iceman's environment. In: Bortenschlager, S., Oeggl, K. (Eds.), The Iceman and his natural Environment, vol. 4, pp. 1124.

Brachmann, R., 1979. Glaciers des Alpes. Bibliothèque des Arts.
Brun, C., 2011. Anthropogenic indicators in pollen diagrams in eastern France: a critical review. Vegetation History and Archaeobotany 20 (2), 135142.

Carcaillet, C., Ali, A.A., Blarquez, O., Genries, A., Mourier, B., Bremond, L. 2009. Spatial variability of fire history in subalpine forests: from natural to cultural regimes. Ecoscience 16 (1), 112.

Colombaroli, D., Beckmann, M., van der Knaap, W.O., Curdy, P., Tinner, W., 2013. Changes in biodiversity and vegetation composition in the central Swiss Alps during the transition from pristine forest to first farming. Diversity and Distributions 19 (2), 157170.

Colombaroli, D., Henne, P., Kaltenrieder, P., Gobet, E., Tinner, W., 2010. Species responses to fire, climate and human impact at tree line in the Alps as evidenced by paleoenvironmental records and a dynamic simulation model. Journal of Ecology 98 (6), 13461357.

Conedera, M., Tinner, W., Neff, C., Meurer, M., Dickens, A., Krebs, P., 2009. Reconstructing past fire regimes: methods, applications, and relevance to fire management and conservation. Quaternary Science Reviews 28 (5 6), 555576.

Cugny, C., Mazier, F., Galop, D., 2010. Modern and fossil non-pollen palynomorphs from the Basque mountains (western Pyrenees, France): the use of coprophilous fungi to reconstruct pastoral activity. Vegetation History and Archaeobotany 19 (5 6), 391408.

Davis, O.K., Shafer, D.S., 2006. Sporormiella fungal spores, a palynological means of detecting herbivore density. Palaeogeography, Palaeoclimatology, Palaeoecology 237 (1), 4050 .

Dearing, J.A., Battarbee, R.W., Dikau, R., Larocque, I., Oldfield, F., 2006. Human environment interactions: learning from the past. Regional Environmental Change $6\left(\begin{array}{ll}1 & 2\end{array}\right), 116$.

Dietre, B., Gauthier, É., Gillet, F., 2012. Modern pollen rain and fungal spore assemblages from pasture woodlands around Lake Saint-Point (France). Review of Palaeobotany and Palynology 186, 6989.

Doyen, E., Vannière, B., Bichet, V., Gauthier, É., Richard, H., Petit, C., 2013. Vegetation history and landscape management from 6500 to $1500 \mathrm{cal}$. BP at Lac d'Antre, Gallo-Roman sanctuary of Villards d'Héria, Jura, France. Vegetation History and Archaeobotany 22 (2), 8397.

Ejarque, A., Miras, Y., Riera, S., Palet, J., Orengo, H., 2010. Testing micro-regional variability in the Holocene shaping of high mountain cultural landscapes: a palaeoenvironmental case-study in the eastern Pyrenees. Journal of Archaeological Science 37 (7), 14681479.

Ellis, M.B., Ellis, J.P., 1997. Microfungi on Land Plant: an Identification Handbook. The Richmond Publishing Co. Ltd., London.

Fægri, K., Iversen, J., Kaland, P.E., Krzywinski, K., 1993. Bestimmungsschlüssel für die nordwesteuropäische Pollenflora. Gustav Fischer Verlag, Jena.

Finsinger, W., Tinner, W., 2006. Holocene vegetation and land-use changes in response to climatic changes in the forelands of the southwestern Alps, Italy. Journal of Quaternary Science 21 (3), 243258.

Finsinger, W., Tinner, W., 2007. Pollen and plant macrofossils at Lac de Fully (2135 m asl): Holocene forest dynamics on a highland plateau in the Valais, Switzerland. The Holocene 17 (8), 11191127.

Frei, R., Biino, G., Prospert, C., 1995. Dating a Variscan pressure-temperature loop with staurolite. Geology 23 (12), 10951098.

Gauthier, É., Bichet, V., Massa, C., Petit, C., Vannière, B., Richard, H., 2010. Pollen and non-pollen palynomorphs evidence of medieval farming activities in southwestern Greenland. Vegetation History and Archaeobotany 19 (5 6), 427438.

Gobet, E., Tinner, W., Hochuli, P.A., van Leeuwen, J.F., Ammann, B., 2003. Middle to Late Holocene vegetation history of the Upper Engadine (Swiss Alps): the role of man and fire. Vegetation History and Archaeobotany 12 (3), 143163.

Graf, M.-T., Chmura, G.L., 2006. Development of modern analogues for natural, mowed and grazed grasslands using pollen assemblages and coprophilous fungi. Review of Palaeobotany and Palynology 141 (1), 139149.

Grimm, E.C. 1987. CONISS: a FORTRAN 77 program for stratigraphically constrained cluster analysis by the method of incremental sum of squares. Computers \& Geosciences 13 (1), 1335.

Grimm, E.C., 2011. Tilia. Illinois State Museum, Springfield, Illinois, USA. Version 1.7.16.

Grimm, E.C., 2013. Tilia. Illinois State Museum, Springfield, Illinois, USA. Version 2.0.4.

Haas, J.N., Richoz, I., Tinner, W., Wick, L., 1998. Synchronous Holocene climatic oscillations recorded on the Swiss Plateau and at timberline in the Alps. The Holocene 8 (3), 301309.

Haas, J.N., Walde, C., Wild, V., 2007. Holozäne Schneelawinen und prähistorische Almwirtschaft und ihr Einfluss auf die subalpine Flora und Vegetation der Schwarzensteinalm im Zemmgrund (Zillertal, Tirol, Österreich). In: Luzian, R., Pindur, P. (Eds.), Prähistorische Lawinen. Nachweis und Analyse holozäner Lawinenereignisse in den Zillertaler Alpen, Österreich. Mitteilungen der Kommission für Quartärforschung der Österreichischen Akademie der Wissenschaften 16, pp. 191226.

Hajdas, I., 2008. Radiocarbon dating and its applications in Quaternary studies. Eiszeitalter und Gegenwart Quaternary Science Journal 57, 224.

Hertl, A., Kerschner, H., 2001. Untersuchungen zur spätglazialen und frühholozänen Gletscher- und Klimageschichte in der österreichischen Silvrettagruppe. Innsbrucker Geographischen Gesellschaft: Innsbrucker Jahresbericht 1999/2000, pp. 148156

Innes, J.B., Blackford, J.J., 2003. The ecology of late Mesolithic woodland disturbances: model testing with fungal spore assemblage data. Journal of Archaeological Science 30 (2), 185194. 
Jacomet, S., 2008. Plant economy and village life in Neolithic lake dwellings at the time of the Alpine Iceman. Vegetation History and Archaeobotany 18 (1), 4759

Juggins, S., 2012. rioja: Analysis of Quaternary Science Data, R package version (0.8-5)

Kaltenrieder, P., Tinner, W., Ammann, B., 2005. Zur Langzeitökologie des LärchenArvengürtels in den südlichen Walliser Alpen. Botanica Helvetica 115 (2), 137154

Kofler, W. Krapf, V., Oberhuber, W. Bortenschlager, S, 2005. Vegetation responses to the $8200 \mathrm{cal}$. BP cold event and to long-term climatic changes in the Eastern Alps: possible influence of solar activity and North Atlantic freshwater pulses. The Holocene 15 (6), 779788

Kołaczek, P., Fałkiewicz-Kozieł, B., Karpinska-Kołaczek, M., Gałka, M., 2010. The last two millennia of vegetation development and human activity in the OrawaNowy Targ Basin (south-eastern Poland). Acta Palaeobotanica 50 (2), 133148

Körner, C., 1998. A re-assessment of high elevation treeline positions and their explanation. Oecologia 115 (4), 445459.

Laine, A., Gauthier, É., Garcia, J.-P., Petit, C., Cruz, F., Richard, H., 2010. A threethousand-year history of vegetation and human impact in Burgundy (France) reconstructed from pollen and non-pollen palynomophs analysis. Comptes Rendus Biologies 333 (11 12), 850857.

Latałowa, M., 1992. Man and vegetation in the pollen diagrams from Wolin Island (NW Poland). Acta Palaeobotanica 32 (1), 123249.

Lisitsyna, O.V., Giesecke, T., Hicks, S., 2011. Exploring pollen percentage threshold values as an indication for the regional presence of major European trees. Review of Palaeobotany and Palynology 166 (3 4), 311324

MacArthur, R.H., 1957. On the relative abundance of bird species. Proceedings of the National Academy of Sciences 43 (3), 293295.

Magny, M., 2007. Lake level studies West-Central-Europe. In: Elias, S.A. (Ed.) Encyclopedia of Quaternary Science. Elsevier, Oxford, pp. 13891399.

Magny, M., Leuzinger, U., Bortenschlager, S., Haas, J.N., 2006. Tripartite climate reversal in Central Europe 5600-5300 years ago. Quaternary Research 65 (1) 319.

Maher, L., 1981. Statistics for microfossil concentration measurements employing samples spiked with marker grains. Review of Palaeobotany and Palynology 32 (2 3), 153191

Miola, A., 2012. Tools for Non-Pollen Palynomorphs (NPPs) analysis: a list of Quaternary NPP types and reference literature in English language (1972 2011). Review of Palaeobotany and Palynology 186, 142161

Moe, D., 1974. Identification key for trilete microspores of Fennoscandian Pteridophyta. Grana 14 (2 3), 132142

Nicolussi, K., 2012. Jahrringdaten zur früh- und mittelholozänen Baumgrenze in der Silvretta. In: Reitmaier, T. (Ed.), Letzte Jäger, erste Hirten: Hochalpine Archäologie in der Silvretta. Archäologischer Dienst Graubünden, Chur, pp. 8798.

Patterson III, W.A., Edwards, K.J., Maguire, D.J., 1987. Microscopic charcoal as a fossil indicator of fire. Quaternary Science Reviews 6 (1), 323.

Pott, R., Hüppe, J. Remy, D. Bauerochse, A., Katenhusen, O, 1995. Paläoökologische Untersuchungen zu holozänen Waldgrenzschwankungen im oberen Fimberta (Val Fenga, Silvretta, Ostschweiz). Phytocoenologia 25, 363398.

Punt, W. (Ed.), 1976. The Northwest European Pollen Flora, I. Elsevier Scientific Publishing Company, Amsterdam.

Punt, W., Blackmore, S. (Eds.), 1991. The Northwest European Pollen Flora, VI. Elsevier, Amsterdam.

Punt, W., Blackmore, S., Clarke, G.C. (Eds.), 1988. The Northwest European Pollen Flora, V. Elsevier, Amsterdam.

Punt, W., Clarke, G.C. (Eds.), 1980. The Northwest European Pollen Flora, II. Elsevier Scientific Publishing Company, Amsterdam.

Punt, W., Clarke, G.C. (Eds.), 1981. The Northwest European Pollen Flora, III. Elsevier Scientific Publishing Company, Amsterdam.

Punt, W., Clarke, G.C. (Eds.), 1984. The Northwest European Pollen Flora, IV. Elsevier, Amsterdam.

R Core Team, 2013. R: a Language and Environment for Statistical Computing. R Foundation for Statistical Computing, Vienna, Austria. Version 3.0.2.

Reille, M., 1992. Pollen et spores d'Europe et d'Afrique du Nord. Laboratoire de Botanique Historique et Palynologie, Marseille.

Reimer, P.J., Baillie, M.G., Bard, E., Bayliss, A., Beck, J.W., Blackwell, P.G., Ramsey, C.B., Buck, C.E., Burr, G.S., Edwards, R.L., 2009. IntCal09 and Marine09 radiocarbon age calibration curves, 0 50,000 years cal BP. Radiocarbon 51 (4), 11111150.

Reitmaier, T., 2010. Letzte Jäger, erste Hirten. Rückwege 2007 2010, ein Zwischenbericht. In: Reitmaier, T. (Ed.), Letzte Jäger, erste Hirten: Hochalpine Archäologie in der Silvretta. University of Zürich, pp. 950.

Reitmaier, T., 2012. Letzte Jäger, erste Hirten. Hochalpine Archäologie in der Silvretta 2007 2012. In: Reitmaier, T. (Ed.), Letzte Jäger, erste Hirten: Hochalpine Archäologie in der Silvretta. Archäologischer Dienst Graubünden, Chur, pp. 965.

Reitmaier, T., Lambers, K., Walser, C., Zingman, I., Haas, J.N., Dietre, B., Reidl, D. Hajdas, I., Nicolussi, K., Kathrein, Y., Naef, L., Kaiser, T., 2013. Alpine Archäologie in der Silvretta. Archäologie Schweiz 36 (1), 415.

Remy, D., 2012. Waldgrenze und Waldgrenzschwankungen in der Silvretta/Zentralalpen - Funde von Pinus cembra oberhalb der potentiellen Waldgrenze im Oberen Fimbertal. Ber. d. Reinh.-Tüxen-Ges 24, 6175.

Rey, F., Schwörer, C., Gobet, E., Colombaroli, D., van Leeuwen, J.F., Schleiss, S., Tinner, W., 2013. Climatic and human impacts on mountain vegetation at
Lauenensee (Bernese Alps, Switzerland) during the last 14,000 years. The Holocene 23 (10), 14151427.

Röpke, A., Stobbe, A. Oeggl, K., Kalis, AJ. Tinner, W, 2011. Late-Holocene land-use history and environmental changes at the high altitudes of St Antönien (Switzerland, Northern Alps): combined evidence from pollen, soil and treering analyses. The Holocene 21 (3), 485498.

Schwörer C. Kaltenrieder, P., Glur L., Berlinger, M., Elbert, J., Frei, S., Gilli, A., Hafner, A Anselmetti, F.S., Grosjean, M., Tinner, W., 2014. Holocene climate, fire and vegetation dynamics at the treeline in the Northwestern Swiss Alps. Vegetation History and Archaeobotany. http://dx.doi.org/10.1007/s00334-013-0411-5.

Seiwald, A., 1980. Beitrage zur Vegetationsgeschichte Tirols IV: Natzer Plateau Villanderer Alm. Berichte des naturwissenschaftlich-medizinischen Vereins in Innsbruck 67, 3172.

Stockmarr, J., 1971. Tablets with spores used in absolute pollen analysis. Pollen et Spores 13, 615621.

Stuiver, M., Polach, H.A., 1977. Discussion reporting of ${ }^{14} \mathrm{C}$ data. Radiocarbon 19 (3), 355363.

Swain, A.M., 1973. A history of fire and vegetation in northeastern Minnesota as recorded in lake sediments. Quaternary Research 3 (3), 383396.

Synal, H.-A., Stocker, M., Suter, M., 2007. MICADAS: a new compact radiocarbon AMS system. Nuclear Instruments and Methods in Physics Research Section B: Beam Interactions with Materials and Atoms 259 (1), 713.

Thiébault, S., 2010. Archéologie environnementale de la France. La Découverte, Paris.

Tinner, W., 2007. Treeline studies. Encyclopedia of Quaternary Science 3, 2374 2384.

Tinner, W., Ammann, B., Germann, P., 1996. Treeline fluctuations recorded for 12,500 years by soil profiles, pollen, and plant macrofossils in the Central Swiss Alps. Arctic and Alpine Research 28 (2), 131147.

Tinner, W., Kaltenrieder, P., 2005. Rapid responses of high-mountain vegetation to early Holocene environmental changes in the Swiss Alps. Journal of Ecology 93 (5), 936947.

Tinner, W., Lotter, A.F., 2001. Central European vegetation response to abrupt climate change at $8.2 \mathrm{ka}$. Geology 29 (6), 551554.

Tinner, W., Lotter, A.F., 2006. Holocene expansions of Fagus silvatica and Abies alba in Central Europe: where are we after eight decades of debate? Quaternary Science Reviews 25 (5), 526549.

Tinner, W., Theurillat, J., 2003. Uppermost limit, extent, and fluctuations of the timberline and treeline ecocline in the Swiss Central Alps during the past 11,500 years. Arctic, Antarctic, and Alpine Research 35 (2), 158169.

van der Knaap, W.O., van Leeuwen, J.F., Ammann, B., 2001. Seven years of annual pollen influx at the forest limit in the Swiss Alps studied by pollen traps: relations to vegetation and climate. Review of Palaeobotany and Palynology 117 (1 3), 3152 .

van der Knaap, W.O, van Leeuwen, J.F, Goslar, T, Krisai, R., Tinner, W, 2012. Human impact on vegetation at the Alpine tree-line ecotone during the last millennium: lessons from high temporal and palynological resolution. Vegetation History and Archaeobotany 21 (1), 3760.

van Geel, B., Aptroot, A., 2006. Fossil ascomycetes in Quaternary deposits. Nova Hedwigia 82 (3 4), 313329.

van Geel, B., Berglund, B.E., 2000. A causal link between a climatic deterioration around 850 cal BC and a subsequent rise in human population density in NWEurope? Terra Nostra 7, 126130.

van Geel, B., Buurman, J., Brinkkemper, O., Schelvis, J., Aptroot, A., van Reenen, G., Hakbijl, T. 2003. Environmental reconstruction of a Roman Period settlement site in Uitgeest (The Netherlands), with special reference to coprophilous fungi. Journal of Archaeological Science 30 (7), 873883.

van Geel, B., Hallewas, D., Pals, J., 1983. A late Holocene deposit under the Westfriese Zeedijk near Enkhuizen (prov. of Noord-Holland, The Netherlands) palaeoecological and archaeological aspects. Review of Palaeobotany and Palynology 38 (3 4), 269335.

van Geel, B., Renssen, H., 1998. Abrupt climate change around 2,650 BP in NorthWest Europe: evidence for climatic teleconnections and a tentative explanation. In: Issar, A.S., Brown, N.E. (Eds.), Water, Environment and Society in Times of Climatic Change. Springer, pp. 2141

Veski, S., Seppä, H., Ojala, A.E.K., 2004. Cold event at 8200 yr B.P. recorded in annually laminated lake sediments in eastern Europe. Geology 32 (8), 681684

Welten, M., 1982. Pollenanalytische Untersuchungen zur Vegetationsgeschichte des Schweizerischen Nationalparks. Ergebnisse der wissenschaftlichen Untersuchungen im Schweizerischen Nationalpark 16, 143.

Wick, L., Tinner, W., 1997. Vegetation changes and timberline fluctuations in the Central Alps as indicators of Holocene climatic oscillations. Arctic and Alpine Research 29 (4), 445458.

Wickham, H., 2009. ggplot2: Elegant Graphics for Data Analysis. Springer New York.

Zoller, H., Erny-Rodman, C., 1994. Epochen der Landschaftsentwicklung im Unterengadin. In: Lotter, A.F., Ammann, B. (Eds.), Festschrift Gerhard Lang. Dissertationes Botanicae 234, pp. 565581.

Zoller, H. Erny-Rodmann, C. Punchakunnel, P., 1996. The History of Vegetation and Land Use in the Lower Engadine (Switzerland). Pollen Records of the Last 13000 Years. In: Nationalpark-Forschung in der Schweiz, vol. 86. J. Cramer, Berlin, pp. 161. 